\title{
Behavior of Normal Concrete Reinforced With Fiber
}

\author{
Prabowo Setiyawan ${ }^{1 *}$ \\ ${ }^{1}$ Civil Engineering Department, Universitas Islam Sultan Agung, Jl. Raya Kaligawe km.4 Semarang \\ 50112, Indonesia \\ * Corresponding author: prabowo@unissula.ac.id
}

(Received: October 14 ${ }^{\text {th }} 2021$; Accepted: October 21 ${ }^{\text {st }} 2021$ )

\begin{abstract}
Concrete is a material with the ability to withstand a fairly high pressure, yet it has a low ability to withstand tension. To be utilized as a structure material, improvements need to be made to increase its tensile strength. Addition of fiber in the concrete mixture is recognized to be one among the existing methods to increase the tensile strength. Considering its high tensile strength, Menjalin was selected in the study as a base material for the fiber utilized in the concrete mixture. This study aimed to examine the compressive strength, the split tensile strength, the flexural and elastic modulus of the normal concrete with Menjalin fibers. The examination was conducted using a cylinder with the diameter of $15 \mathrm{~cm}$ and the height of $30 \mathrm{~cm}$ and a beam with the size of $15 \times 15 \times 60 \mathrm{~cm}$. Fiber addition was $0.65 \%$ of the total concrete materials with various fiber lengths ranging from $2.5 \mathrm{~cm}, 5 \mathrm{~cm}, 7.5 \mathrm{~cm}$ to $10 \mathrm{~cm}$. The experiment was made by the means of a concrete cylinder compressive test and a flexural test of unreinforced concrete blocks. Results of the study showed, at the age of 21 days, the highest average compressive strength value of $194.37 \mathrm{~kg} / \mathrm{cm}^{2}$ and the split tensile strength of $30.43 \mathrm{~kg} / \mathrm{cm}^{2}$ in the concrete with fiber of $5 \mathrm{~cm}$ long were obtained. The highest flexural modulus value of concrete occurred in the specimen with the fiber length of $7.5 \mathrm{~cm}(55.7$ $\mathrm{kg} / \mathrm{cm}^{2}$ ), while the highest elasticity of concrete occurred in the specimen with the fiber length of $5 \mathrm{~cm}$ $\left(2.45 \times 105 \mathrm{~kg} / \mathrm{cm}^{2}\right)$.
\end{abstract}

Keywords: fibrous concrete, compressive strength, split tensile strength, flexural modulus, elastic modulus

\section{Introduction}

Concrete can be defined as a building material of construction whose properties can be determined in advance by conducting careful planning and supervision of the selected materials (Wuryati and Candra, 2021). As a building material, concrete structures have advantages; they can be fabricated based the construction needs, can withstand heavy loads, are resistant to high temperatures and have low maintenance costs. However, the shape is static; thus, it is difficult to change, the execution requires high accuracy, it is very heavy and it has high sound reflectivity.

The value of the tensile strength of concrete is relatively small compared to the value of its compressive strength, which is in the range between $9 \%$ to $15 \%$. This is a weak point commonly found in an ordinary concrete. To increase tensile strength of a concrete, fibers can be added into the concrete mixture.

Originating from plants, Menjalin fiber is classified into natural fibers which can be employed into design of concrete mixture. This fiber has a high tenacity and tensile strength. Therefore, by adding the fiber into normal concrete mixture, the fiber concrete produced is expected to have a higher tensile strength value. 


\section{Previous Studies}

Fiber concrete can be defined as a concrete made of Portland cement or other hydraulic binders added with fine and coarse aggregates, and water, then reinforced with fiber (Hannant, 1978).

Although design of structure allows concrete to be in compression, the tensile part of the concrete will in fact still withstand the tensile force, even if only in small amounts where it causes hair cracks before the reinforcement optimally supports the tensile concrete (Sudarmoko, 1993). Structurally, these cracks may not be dangerous, but in terms of durability, it will be quite influential.

Considerable amounts of studies have been conducted to examine the use of fibers in concrete mixtures, especially steel fibers. Compared to other types of fiber, this fiber has the advantage of high tensile strength and modulus of elasticity, in addition to having other advantageous characteristics when they are in concrete mixture. For example, it does not change in term of shape due to the influence of alkali in cement, it has a very high adhesion to the concrete mixture and has mechanical properties which will not change with time. Other than the advantages, steel fiber also has disadvantages; (1) it has a risk of corrosion if the concrete is not in a protected condition; (2) it has relatively high specific gravity which makes the weight of the concrete increase; and (3) it has high adhesive properties which trigger a balling effect, the fibers are not spread evenly when mixed with the concrete mixture.

Similar with western countries, many construction projects in Indonesia have been utilizing steel fiber of rebar tie wire for concrete mixture. The use of this wire was varied between $60 \mathrm{~mm}, 80$ $\mathrm{mm}$, and $100 \mathrm{~mm}$. Employing this wire of $1 \%$ concrete volume can increase the tensile strength by $47 \%$ and increase the compressive strength by $25 \%$. Ezeldin and Hsu (1992) reported the concrete properties possible for improvement due to the addition of fiber include:

a. Ductility, the ability of a material to absorb energy

b. Resistance to shock loads

c. Capability of tensile strength and bending moment

d. Resistance to fatigue

e. Resistance to shrinkage

f. Resistance to wear

To make the properties of concrete better, the fibers used in the concrete mixture must meet the following conditions (Zollo, 1987, Riyana, 1996):

a. Durability

The fibers must be resistant to the concrete environment. Factors which affect this durability include reactions to alkalis, mechanical abrasion resistance during the process of mixing and working the concrete, in addition to alteration in phase or shape due to the changes in temperature.

b. Bonding

Mechanical and chemical bonding or anchoring the fibers inward is important to obtain the desired strength. This property is very difficult to measure and to elevate that it greatly affects the composite properties.

c. Mechanical properties

These properties include strength, hardness and plasticity. Fiber is expected to have relatively high strength, hardness, plasticity and the ability to absorb energy. This property is important both during loading and in resisting cracking.

d. Fiber is expected to have properties which are easy to work with in the sense that its distribution can be evenly distributed throughout the concrete without balling (clumping) in order to get an even effect.

In general, improving the tensile strength of concrete becomes primary focus of adding fiber into concrete. When the concrete begins to crack before crumbling, the fiber will block the cracks, 
therefore, the concrete remains ductile. However, the addition of fiber does not significantly affect the compressive strength. This strength is more influenced by the hardness and the shape of the aggregate. These hardness and shape can lock the compressive strength and bind if the utilized fiber has a higher modulus of elasticity than the concrete and the aggregate (Sudarmoko, 1993).

\section{Research Methods}

The materials used in this research were Portland Cement Type 1, Menjalin Fiber with a thickness of $\pm 1.5 \mathrm{~mm}$ and a width of $\pm 5 \mathrm{~mm}$, Fine aggregate from Muntilan sand, Coarse aggregate with a maximum size of $40 \mathrm{~mm}$, Clean water from artesian wells. The testing objects used in this study were cylinders of $15 \times 30 \mathrm{~cm}$ and beams of $15 \times 15 \times 60 \mathrm{~cm}$ as shown in Table 1 .

Table 1. Types of Test Objects

\begin{tabular}{|c|c|c|c|c|c|c|c|}
\hline \multirow{3}{*}{ Testing Types } & \multirow{3}{*}{ Testing Objects } & \multicolumn{5}{|c|}{ Number of Testing Objects } & \multirow{3}{*}{ Amount } \\
\hline & & \multirow{2}{*}{$\begin{array}{c}\text { Normal } \\
\text { Concrete }\end{array}$} & \multicolumn{4}{|c|}{ Fiber proportion of $0.65 \%$} & \\
\hline & & & $2.5 \mathrm{~cm}$ & $5 \mathrm{~cm}$ & $7.5 \mathrm{~cm}$ & $10 \mathrm{~cm}$ & \\
\hline $\begin{array}{l}\text { Split tensile } \\
\text { strength }\left(f_{\mathrm{t}}\right)\end{array}$ & Cylinder $15 \times 30 \mathrm{~cm}$ & 3 & 3 & 3 & 3 & 3 & 15 \\
\hline $\begin{array}{l}\text { Compressive } \\
\text { strength }\left(f^{1}\right)\end{array}$ & Cylinder $15 \times 30 \mathrm{~cm}$ & 3 & 3 & 3 & 3 & 3 & 15 \\
\hline $\begin{array}{l}\text { Concrete } \\
\text { flexural } \\
\text { modulus }\end{array}$ & Beam 15x15x60 cm & 3 & 3 & 3 & 3 & 3 & 15 \\
\hline $\begin{array}{l}\text { Concrete } \\
\text { Elastic } \\
\text { Modulus }\end{array}$ & Cylinder $15 \times 30 \mathrm{~cm}$ & 3 & 3 & 3 & 3 & 3 & 15 \\
\hline Total of Test $\mathrm{Ob}$ & & & & & & & 60 \\
\hline
\end{tabular}

The testing procedure in this study was carried out in accordance with the provisions stipulated in the SNI (Indonesia National Standard) as follows:

a. Split Tensile Strength Test (SNI 03-2491-2002)

b. Compressive Strength Test (SNI 1974: 2011)

c. Flexural Modulus Test (SNI 4431: 2011)

d. Elastic Modulus Test (SNI 2847-2013)

\section{Result and Discussion}

Results of the fiber volume weight testing are shown in Table 2.

Table 2. Fiber Volume Weight

\begin{tabular}{ccccc}
\hline Testing & $\begin{array}{c}\text { Fiber } \\
\text { weight } \\
\text { (grams) }\end{array}$ & $\begin{array}{c}\text { Fiber } \\
\text { Volume } \\
(\mathrm{ml})\end{array}$ & $\begin{array}{c}\text { Fiber Volume } \\
\text { Weight } \\
\text { (grams/ml) }\end{array}$ & $\begin{array}{c}\text { Volume } \\
\text { Weight } \\
\text { Average } \\
\text { (grams/ml) }\end{array}$ \\
\hline I & 1.7 & 3.1 & 0.548 & \\
II & 2.0 & 3.5 & 0.576 & 0.561 \\
III & 2.3 & 4.1 & 0.560 & \\
\hline
\end{tabular}


Based on the testing results, the fiber volume weight of 0.561 grams $/ \mathrm{ml}$ was taken. The value of the tension or the tensile strength of the fiber is shown in Table 3.

Table 3. Fiber Tensile Strength

\begin{tabular}{|c|c|c|c|c|c|c|}
\hline Testing & $\begin{array}{l}\text { Diameter } \\
(\mathrm{mm})\end{array}$ & $\begin{array}{l}\text { Width } \\
(\mathrm{cm})\end{array}$ & $\begin{array}{l}\text { Width } \\
\text { average } \\
\left(\mathrm{cm}^{2}\right)\end{array}$ & $\begin{array}{l}\text { Load } \\
(\mathrm{kg})\end{array}$ & $\begin{array}{r}\text { Tension } \\
\left(\mathrm{kg} / \mathrm{cm}^{2}\right)\end{array}$ & $\begin{array}{l}\text { Tension } \\
\text { average } \\
\left(\mathrm{kg} / \mathrm{cm}^{2}\right)\end{array}$ \\
\hline \multirow{3}{*}{ I } & 7.5 & 0.441 & \multirow{3}{*}{0.504} & \multirow{3}{*}{750} & \multirow{3}{*}{1488.09} & \multirow{9}{*}{1474.16} \\
\hline & 7.8 & 0.478 & & & & \\
\hline & 8.7 & 0.594 & & & & \\
\hline \multirow{3}{*}{ II } & 6.8 & 0.363 & & & & \\
\hline & 6.8 & 0.363 & 0.345 & 500 & 1449.27 & \\
\hline & 6.3 & 0.311 & & & & \\
\hline \multirow{3}{*}{ III } & 7.1 & 0.396 & \multirow{3}{*}{0.404} & \multirow{3}{*}{600} & \multirow{3}{*}{1485.14} & \\
\hline & 6.8 & 0.363 & & & & \\
\hline & 7.6 & 0.453 & & & & \\
\hline
\end{tabular}

Based on the calculation result in table 3, Menjalin tensile strength of $1474.16\left(\mathrm{~kg} / \mathrm{cm}^{2}\right)$ was taken. The test of concrete compressive strength was conducted using 3 units of testing objects for each type of mixture as shown in table 4 when the concrete was 21 days old.

Table 4. Testing result of concrete compressive strength

\begin{tabular}{ccccc}
\hline $\begin{array}{c}\text { Code of testing } \\
\text { objects }\end{array}$ & $\begin{array}{c}\text { Fiber } \\
\text { length }(\mathrm{cm})\end{array}$ & $\begin{array}{c}\text { Maximum } \\
\text { load }(\mathrm{kg})\end{array}$ & $\begin{array}{c}\text { Tension } \\
\left(\mathrm{kg} / \mathrm{cm}^{2}\right)\end{array}$ & $\begin{array}{c}\text { Tension average } \\
\left(\mathrm{kg} / \mathrm{cm}^{2}\right)\end{array}$ \\
\hline P.0.1 & - & 33.50 & 189.66 & \\
P.0.2 & - & 34.00 & 192.49 & 190.60 \\
P.0.3 & - & 33.50 & 189.66 & \\
\hline P.1.1 & 2.5 & 34.50 & 195.32 & \\
P.1.2 & 2.5 & 34.00 & 192.49 & 192.49 \\
P.1.3 & 2.5 & 33.50 & 189.66 & \\
\hline P.2.1 & 5.0 & 34.50 & 192.32 & \\
P.2.2 & 5.0 & 34.00 & 192.49 & 194.37 \\
P.2.3 & 5.0 & 34.50 & 195.32 & \\
\hline P.3.1 & 7.5 & 33.50 & 189.66 & \\
P.3.2 & 7.5 & 34.00 & 192.49 & 191.54 \\
P.3.3 & 7.5 & 34.00 & 192.49 & \\
\hline P.4.1 & 10 & 33.00 & 186.83 & \\
P.4.2 & 10 & 33.50 & 189.66 & 187.77 \\
P.4.3 & 10 & 33.00 & 186.83 & \\
\hline
\end{tabular}

The test of concrete split tensile strength was also conducted using 3 units of testing objects for each type of mixture as shown in table 5 when the concrete was 21 days old. 
Table 5. The testing result of concrete split tensile strength

\begin{tabular}{ccccc}
\hline $\begin{array}{c}\text { Code of testing } \\
\text { objects }\end{array}$ & $\begin{array}{c}\text { Fiber } \\
\text { length }(\mathrm{cm})\end{array}$ & $\begin{array}{c}\text { Maximum } \\
\text { load }(\mathrm{kg})\end{array}$ & $\begin{array}{c}\text { Tension } \\
\left(\mathrm{kg} / \mathrm{cm}^{2}\right)\end{array}$ & $\begin{array}{c}\text { Tension average } \\
\left(\mathrm{kg} / \mathrm{cm}^{2}\right)\end{array}$ \\
\hline T.0.1 & - & 19.50 & 27.60 & \\
T.0.2 & - & 19.50 & 27.60 & 26.89 \\
T.0.3 & - & 18.00 & 25.48 & \\
\hline T.1.1 & 2.5 & 20.00 & 28.31 & \\
T.1.2 & 2.5 & 21.00 & 29.72 & 29.01 \\
T.1.3 & 2.5 & 21.50 & 29.01 & \\
\hline T.2.1 & 5.0 & 21.00 & 29.72 & \\
T.2.2 & 5.0 & 21.50 & 30.43 & 30.43 \\
T.2.3 & 5.0 & 22.00 & 31.14 & \\
T.3.1 & 7.5 & 18.00 & 25.47 & \\
T.3.2 & 7.5 & 19.00 & 27.60 & 26.42 \\
T.3.3 & 7.5 & 18.50 & 26.18 & \\
\hline T.4.1 & 10 & 18.50 & 26.18 & \\
T.4.2 & 10 & 16.50 & 23.35 & 24.53 \\
T.4.3 & 10 & 17.00 & 24.06 & \\
\hline
\end{tabular}

From Table 4 and Table 5, the values of compressive strength and the highest concrete tensile strength are $194.7 \mathrm{~kg} / \mathrm{cm}^{2}$ and $30.43 \mathrm{~kg} / \mathrm{cm}^{2}$. These values were obtained from the testing objects with the fiber length of $5.0 \mathrm{~cm}$, this was the optimum fiber length.

The test of concrete flexural modulus was conducted using 3 units of testing objects for each mixture when the concrete was 21 days old. See table 6 for the result of the flexural modulus and table 7 for concrete elastic modulus.

Table 6. The testing results of concrete flexural modulus

\begin{tabular}{ccccc}
\hline $\begin{array}{c}\text { Code of testing } \\
\text { objects }\end{array}$ & $\begin{array}{c}\text { Fiber } \\
\text { length }(\mathrm{cm})\end{array}$ & $\begin{array}{c}\text { Maximum } \\
\text { load }(\mathrm{kg})\end{array}$ & $\begin{array}{c}\text { Tension } \\
\left(\mathrm{kg} / \mathrm{cm}^{2}\right)\end{array}$ & $\begin{array}{c}\text { Tension average } \\
\left(\mathrm{kg} / \mathrm{cm}^{2}\right)\end{array}$ \\
\hline F.0.1 & - & 2.90 & 51.55 & \\
F.0.2 & - & 2.90 & 51.55 & 51.85 \\
F.0.3 & - & 2.95 & 52.44 & \\
\hline F.1.1 & 2.5 & 2.75 & 48.88 & \\
F.1.2 & 2.5 & 2.80 & 49.77 & 50.06 \\
F.1.3 & 2.5 & 2.90 & 51.55 & \\
\hline F.2.1 & 5.0 & 3.00 & 53.33 & \\
F.2.2 & 5.0 & 3.15 & 56.00 & 54.22 \\
F.2.3 & 5.0 & 3.00 & 53.33 & \\
\hline F.3.1 & 7.5 & 3.25 & 57.77 & \\
F.3.2 & 7.5 & 3.00 & 53.33 & \\
F.3.3 & 7.5 & 3.15 & 56.00 & \\
\hline F.4.1 & 10 & 2.60 & 46.22 & \\
F.4.2 & 10 & 2.80 & 49.77 & \\
F.4.3 & 10 & 2.95 & 52.44 & \\
\hline
\end{tabular}




$$
f_{r}=\frac{P \times L}{b \times d^{2}}
$$

Where,

$f_{r} \quad$ : flexural modulus $\left(\mathrm{kg} / \mathrm{cm}^{2}\right)$

$P \quad:$ maximum load $(\mathrm{kg})$

$L \quad$ : span length $(\mathrm{cm})$

$b$ : beam height $(\mathrm{cm})$

$d$ : beam height $(\mathrm{cm})$

Table 7. The testing results of concrete elastic modulus $\left(E_{\mathrm{c}}\right)$

\begin{tabular}{|c|c|c|c|c|}
\hline $\begin{array}{c}\text { Code of testing } \\
\text { objects }\end{array}$ & $\begin{array}{c}\text { Fiber } \\
\text { length }(\mathrm{cm})\end{array}$ & $\begin{array}{c}\text { Maximum } \\
\text { load }(\mathrm{kg})\end{array}$ & $\begin{array}{c}\text { Elastic modulus } \\
\left(\mathrm{kg} / \mathrm{cm}^{2}\right)\end{array}$ & $\begin{array}{l}\text { Average of elastic } \\
\text { modulus }\left(\mathrm{kg} / \mathrm{cm}^{2}\right)\end{array}$ \\
\hline E. 0.1 & - & 33.667 & $2.00 \times 10^{5}$ & \\
\hline E. 0.2 & - & 33.667 & $2.31 \times 10^{5}$ & $2.39 \times 10^{5}$ \\
\hline E.0.3 & - & 33.667 & $2.86 \times 10^{5}$ & \\
\hline E.1.1 & 2.5 & 34.000 & $1.82 \times 10^{5}$ & \\
\hline E.1.2 & 2.5 & 34.000 & $2.95 \times 10^{5}$ & $2.2 \times 10^{5}$ \\
\hline E.1.3 & 2.5 & 34.000 & $1.82 \times 10^{5}$ & \\
\hline E.2.1 & 5.0 & 34.333 & $2.25 \times 10^{5}$ & \\
\hline E. 2.2 & 5.0 & 34.333 & $2.48 \times 10^{5}$ & $2.45 \times 10^{5}$ \\
\hline E.2.3 & 5.0 & 34.333 & $2.62 \times 10^{5}$ & \\
\hline E.3.1 & 7.5 & 33.833 & $2.35 \times 10^{5}$ & \\
\hline E.3.2 & 7.5 & 33.833 & $2.22 \times 10^{5}$ & $2.29 \times 10^{5}$ \\
\hline E.3.3 & 7.5 & 33.833 & $2.29 \times 10^{5}$ & \\
\hline E.4.1 & 10 & 33.167 & $2.53 \times 10^{5}$ & \\
\hline E. 4.2 & 10 & 33.167 & $1.91 \times 10^{5}$ & $2.26 \times 10^{5}$ \\
\hline E.4.3 & 10 & 33.167 & $2.35 \times 10^{5}$ & \\
\hline
\end{tabular}

Where,

Ec : Elastic Modulus $\left(\mathrm{kg} / \mathrm{cm}^{2}\right)$

$S_{1} \quad$ : Tension on the strain of $0,00005\left(\mathrm{~kg} / \mathrm{cm}^{2}\right)$

$S_{2} \quad:$ Tension on $40 \%$ of the ultimate load $\left(\mathrm{kg} / \mathrm{cm}^{2}\right)$

$\varepsilon_{2} \quad$ : Strain when $\mathrm{S}_{2}$ is achieved

From Table 6, the highest value of the flexural modulus occurred in the testing objects with a fiber length of $7.5 \mathrm{~cm}$ at the weight of $55.7 \mathrm{~kg} / \mathrm{cm}^{2}$. Meanwhile, from Table 7, the highest value of Elastic Modulus occurred in the testing object with a fiber length of $5.0 \mathrm{~cm}$ at the weight of $2.45 \times 10^{5} \mathrm{~kg} / \mathrm{cm}^{2}$.

\section{Conclusions}

From the findings and discussion, it can be concluded:

1. Among the results of testing in the study, Menjalin fiber tensile strength of $1474.16 \mathrm{~kg} / \mathrm{cm}^{2}$ was taken. 
2. Each of the maximum compressive strength and Menjalin tensile strength is $194.37 \mathrm{~kg} / \mathrm{cm}^{2}$ and $30.43 \mathrm{~kg} / \mathrm{cm}^{2}$ occurred in the testing objects with the fiber length of $5 \mathrm{~cm}$ to which it was the optimum fiber length.

To improve accuracy of the research results, the following suggestions need to be considered:

1. The number of test objects for each parameter needs to be increased to represent the actual condition.

2. The test is carried out when the concrete is 28 days old. Therefore, conversion on the quality of the concrete does not have to be conducted.

3. It is necessary to add variations in dimensions and the percentage of the fiber used.

\section{References}

[1] Hannant, D.J. (1978), Fibre Cement and Fibre Concrete, John Wiley and Sons, New York, 219-231

[2] Ezeldin. A.S., Hsu C.T.T. (1992), Optimization of Fibre Concrete Beams, ACI Structural Journal, 89(6), 650-657

[3] Nanni, A., Zollo, R.F. (1987), Behavior of Ferrocement Reintorcement in Tension, ACI Materials Journal, 84(4), 273-277

[4] Riyana, M. (1996), Influence of Addition of Steel Fiber on the No Sand Concrete Compressive and Tensile Strength with Natural Aggregates, Journal of The Civil Eng., Faculty of Engineering, UGM, Yogyakarta (in Indonesian)

[5] Samekto, Wuryanti, Rahmadiyanto, Candra (2001), Concrete Technology, Kanisius, Yogyakarta (in Indonesian)

[6] Sudarmoko (1991), Flexural Strength of Fiber Concrete with Full Scale Model, Research Report, Yogyakarta (in Indonesian)

[7] Sudarmoko (1993), The Influence of Length of Fiber on the Structural Properties of Fiber Concrete, Media Teknik, No.1(April), Faculty of Engineering UGM, Yogyakarta (in Indonesian)

[8] Indonesian National Standard, SNI 1974-2011, Testing Method of Concrete Compressive Strength with Cylinder Specimen (in Indonesian)

[9] Indonesian National Standard, SNI 4431-2011, Testing Method of Flexural Strength of Normal Beams (in Indonesian)

[10] Indonesian National Standard, SNI 2847-2013, Requirements of Structural Concrete of Building (in Indonesian). 